\title{
UASB treatment of a highly alkaline fruit-cannery lye-peeling wastewater
}

\author{
GO Sigge* and TJ Britz \\ Department of Food Science, Stellenbosch University, Private Bag X1, Matieland, 7602, Western Cape, South Africa
}

\begin{abstract}
Anaerobic treatment of a highly alkaline fruit-cannery lye-peeling wastewater was investigated, using an upflow anaerobic sludge blanket (UASB) reactor. Only a short initialisation period was required before COD reduction and OLR had stabilised at 85 to $90 \%$ and $2.40 \mathrm{kgCOD} \cdot \mathrm{m}^{-3} \cdot \mathrm{d}^{-1}$, respectively. With subsequent increases in OLR to $8.1 \mathrm{kgCOD} \cdot \mathrm{m}^{-3} \cdot \mathrm{d}^{-1}$, the COD reduction remained between 85 and $93 \%$ and biogas production peaked at $4.1 \ell \cdot \mathrm{d}^{-1}$ (63\% methane). COD and reactor $\mathrm{pH}$ started to decrease after $111 \mathrm{~d}$. Decreases in gas production were observed by Day 102, decreasing to $2.48 \ell \cdot \mathrm{d}^{-1}$ by Day 111 and $0.93 \ell \cdot \mathrm{d}^{-1}$ after $129 \mathrm{~d}$. Subsequent reductions in the OLR, by reducing influent COD, had no effect on reactor stability. Loss of reactor performance was ascribed to the accumulation of sodium (potentially $>20000 \mathrm{mg} \cdot \ell^{-1}$ ) within the reactor biomass, leading to inhibition of methanogenesis.
\end{abstract}

Keywords: UASB, anaerobic digestion, fruit cannery, treatment, lye

\section{Introduction}

Food-processing industries in South Africa are under increasing pressure to reduce the impact of their wastewater streams on the environment. With the promulgation of the National Environmental Management Act, Act 107 of 1998 (Republic of South Africa, 1998a) and the National Water Act, Act 36 of 1998 (Republic of South Africa, 1998b) the polluter-pays-principle has been adopted, i.e. the polluter pays for the treatment and disposal of the effluent produced. The production of large volumes of untreated wastewater can thus become a very serious financial burden. It is the basic requirement of the legislation on pollution control that wastewater purification be an integral part of industrial processes and that the producer of the wastewater should provide staff, capital and plant to purify the produced wastewater to prescribed standards (Republic of South Africa, 1998a \& b; Gray, 1999). Industrialists should also be aware of the environmental impact of their processes and take steps to minimise these effects (Ikhu-Omoregbe and Masiiwa, 2002).

Due to the nature of the fruit-canning process, large volumes of water are used in the transportation of the product, washing and rinsing, blanching, retorting and cooling operations (Wayman, 1996). Disposal of cannery wastewaters is often complicated by the seasonal nature of the industry, the presence of suspended solids and particulate organics (Harada et al., 1994), cleaning solutions (most commonly sodium hydroxide), often in formulations with various chelating, softening or surfaceactive additives, nitric and phosphoric acids (Mawson, 1997) and sodium hydroxide (used during peeling of certain fruits and vegetables) in the wastewater. In the past these wastewaters had been treated and disposed of by irrigation, lagooning or by means of an activated sludge process (Monson, 1959; Hanks et al., 1968; Gambrell and Peele, 1973; Stalzer, 1976) and irrigation

\footnotetext{
* To whom all correspondence should be addressed.

욤 +27 21 808-3581; fax: +27 21808 3510;

e-mail: GOS@sun.ac.za

Received 18 September 2006; accepted in revised form 22 February 2007.
}

of lye wastewaters was still practised in South Africa as recently as 2000. Currently, most South African fruit canneries recycle their lye solutions as far as possible and dilute the rest by mixing with other cannery wastewaters.

Anaerobic digestion of food processing wastewaters has been successfully implemented (Austermann-Haun et al., 1999; Frankin, 2001). The use of UASB technology to treat seasonal fruit-cannery wastewaters has recently been shown to be a feasible option, with COD reductions of up to $93 \%$ at organic loading rates (OLR) of $10.95 \mathrm{kgCOD} \cdot \mathrm{m}^{-3} \cdot \mathrm{d}^{-1}$ and hydraulic retention times (HRT) of $<12 \mathrm{~h}$ (Trnovec and Britz, 1998). The wastewater originating from the lye-peeling operation, however, requires special attention. This highly alkaline wastewater has COD levels of between 45000 and $50000 \mathrm{mg} \cdot \ell^{-1}$ and a $\mathrm{pH}$ of between 12.5 and 13.8 , impacting significantly on the overall treatability of the cannery wastewater.

The aim of this study was to assess the applicability and effectiveness of the UASB process to treat a fruit-cannery wastewater. The wastewater used in this study was a highly alkaline lye-peeling fruit wastewater obtained from a local fruit cannery.

\section{Material and methods}

\section{Digester design}

A laboratory-scale upflow anaerobic sludge blanket (UASB) reactor was used. The digester had an operational volume of $2.3 \ell$ (total height of $830 \mathrm{~mm}$ and internal diameter of $50 \mathrm{~mm}$ ) and combined a UASB design with an open gas/solids separator at the top of the reactor (McLachlan, 2004). The biogas exited through the top, while the substrate was introduced into the reactor at the base. The overflow of the reactor emptied through a U-shaped tube to prevent any atmospheric oxygen from entering the system. The re-circulation upflow velocity for the reactor was set at $2 \mathrm{~m} \cdot \mathrm{h}^{-1}$. The temperature of the insulated reactor was maintained at $35^{\circ} \mathrm{C}$ using heating tape and an electronic control unit (Meyer et al., 1985). The volume of the biogas was determined using a manometric unit equipped with an electronically control- 


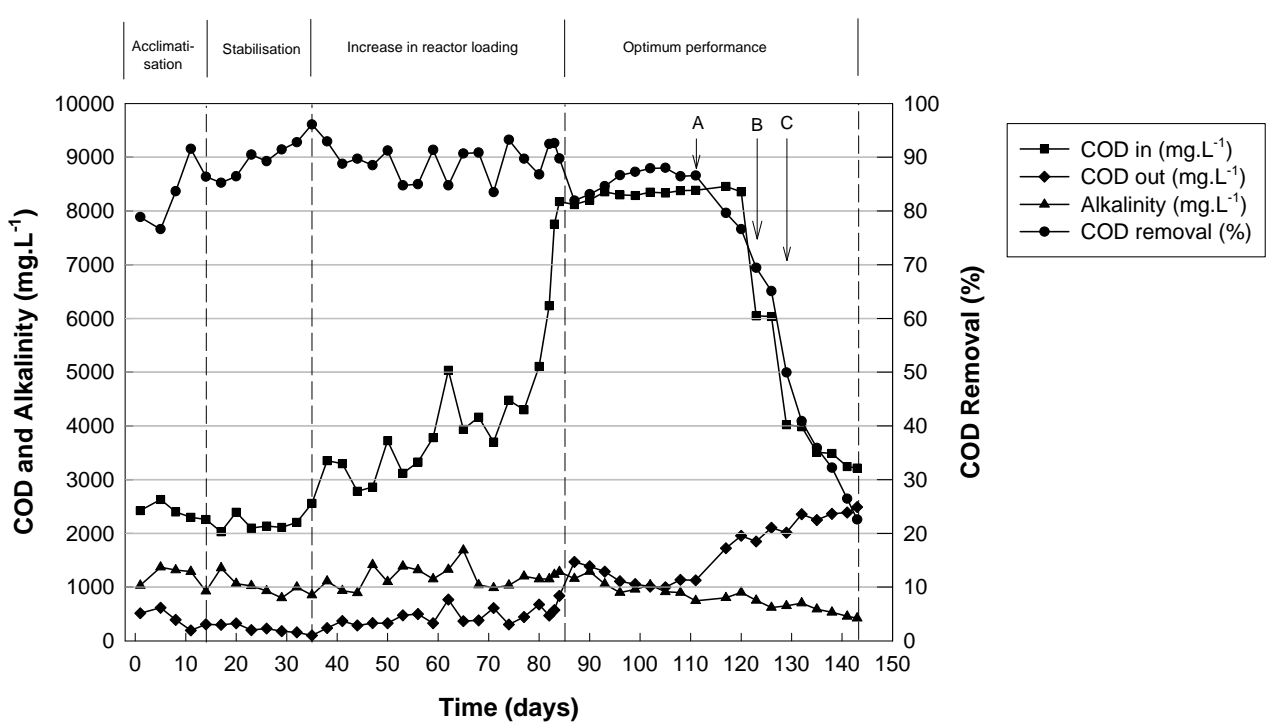

Figure 1

COD reduction efficiency parameters of the UASB reactor treating a high alkaline fruit cannery lye-peeling wastewater $(A-C O D$ reduction decreases after day 111; $B$ - Influent $C O D$ lowered to $6000 \mathrm{mg} \cdot \ell^{1} ; \mathrm{C}$ Influent $C O D$ lowered to $\left.4000 \mathrm{mg} \cdot \ell^{-1}\right)$. Alkalinity $\left(\mathrm{mg} \cdot \ell^{-1}\right)$ $=$ reactor effluent alkalinity as $\mathrm{CaCO}_{3}\left(m g \cdot \ell^{-1}\right)$.

led counter and a gas-tight valve and the volumes corrected to standard temperature and pressure (STP). The substrate was fed semi-continuously to the reactor by means of a peristaltic pump (Watson-Marlow 101) controlled by an electronic timer.

\section{Reactor start-up}

The reactor was seeded with $500 \mathrm{~g}$ of water-drained anaerobic granules from another anaerobic digester giving a settled sludge-bed height of approximately $300 \mathrm{~mm}$. The reactor was then allowed to stabilise for $48 \mathrm{~h}$ in order to allow the bacterial community to acclimatise and fed with a diluted synthetic substrate, and the HRT was set at $24 \mathrm{~h}$. After three weeks this was replaced with a highly alkaline lye-peeling wastewater from a fruit-canning factory with an average COD of $2500 \mathrm{mg} \cdot \ell^{-1}$ (2 030 to $2630 \mathrm{mg} \cdot \ell^{-1}$ ). Once the system had achieved 85 to $90 \%$ COD reduction efficiency the influent COD concentration was increased as well as subsequent increases in the OLR. This was considered to be a 'stable state', during which the variation in reactor performance parameters was less than $10 \%$.

\section{Wastewater and substrate}

The full-strength highly alkaline wastewater had an initial COD of 45000 to $50000 \mathrm{mg} \cdot \ell^{-1}$ and a pH of between 12.5 and 13.5 . The sodium concentration of the wastewater was $c a .40000 \mathrm{mg} \cdot \ell^{-1}$. The full-strength wastewater was allowed to undergo natural fermentation until the $\mathrm{pH}$ was approximately 7.5. The wastewater was then diluted to a COD concentration of $2500 \mathrm{mg} \cdot \ell^{-1}$ and the $\mathrm{pH}$ pegged at 8.5 and used as substrate. The sodium concentration of this diluted substrate was approximately $2000 \mathrm{mg} \cdot \ell^{-1}$.

The composition of the synthetic substrate (in $\mathrm{mg} \cdot \ell^{-1}$ ) was: glucose 1 250; sodium lactate 5 000; urea 500; and $\mathrm{KH}_{2} \mathrm{PO}_{4} 500$. The substrate was also supplemented with $1.0 \mathrm{~m} \ell$ trace element solution (Nel et al., 1985) and the $\mathrm{pH}$ pegged at 8.5 with calcium hydroxide for maximum granule growth. The substrate was then diluted to the required COD concentration of $2500 \mathrm{mg} \cdot \ell^{-1}$.

\section{Analytical methods}

The following parameters were monitored, in duplicate, according to Standard Methods (1998): pH; alkalinity; and total solids (TS). COD and orthophosphate phosphorus were determined colorimetrically using a DR2000 spectrophotometer (Hach Co.,
Loveland, CO) and standardised procedures (Standard Methods, 1998). Sodium ion concentration was determined, in duplicate, using a Varian MPX Inductively Coupled Plasma (ICP) Spectrometer at a wavelength of 589 to $592 \mathrm{~nm}$. The emissions were compared to those of standardised sodium solutions.

The biogas composition was determined on a Varian 3300 GC equipped with a thermal conductivity detector and $2.0 \mathrm{~m}$ x $3.0 \mathrm{~mm}$ i.d. column packed with Hayesep Q (Supelco, Bellefonte, PA), 80/100 mesh. The oven temperature was set at $55^{\circ} \mathrm{C}$ and helium was used as carrier gas at a flow rate of $30 \mathrm{~m} \ell \cdot \mathrm{min}^{-1}$.

\section{Results and discussion}

The UASB reactor efficiency parameters are shown graphically in Figs. 1 and 2. The operation of the UASB reactor has been divided into time periods of reactor start-up (not shown), substrate acclimatisation, reactor stabilisation, increase in reactor loading and optimum performance:

\section{Reactor start-up}

During the start-up period (data not shown) the influent COD of the synthetic substrate was kept at $2500 \mathrm{mg} \cdot \ell^{-1}\left( \pm 150 \mathrm{mg} \cdot \ell^{-1}\right)$ and the COD reduction increased to $93 \%$, averaging $90 \%$ during the third week. The reactor effluent $\mathrm{pH}$ varied between 6.84 and 7.48, the average OLR during the three-week start-up period was $2.45 \mathrm{~kg}$ COD $\cdot \mathrm{m}^{-3} \cdot \mathrm{d}^{-1}$. The reactor effluent alkalinity remained constant at $1000 \mathrm{mg} \cdot \ell^{-1}\left( \pm 110 \mathrm{mg} \cdot \ell^{-1}\right)$. After three weeks the synthetic substrate was replaced with a highly alkaline lye-peeling wastewater.

\section{Substrate acclimatisation}

The average COD load of the highly alkaline lye-peeling wastewater was $2200 \mathrm{mg} \cdot \ell^{-1}$. Initially the COD reduction decreased to $77 \%$ on Day 5 before stabilising and increasing to between 85 and $90 \%$ after $14 \mathrm{~d}$. The reactor effluent alkalinity averaged $1186 \mathrm{mg} \cdot \ell^{-1}\left( \pm 447 \mathrm{mg} \cdot \ell^{-1}\right.$ as $\left.\mathrm{CaCO}_{3}\right)$ (Fig. 1). The reactor $\mathrm{pH}$ varied between 7.18 and 7.27 , the average OLR during this period was $2.40 \mathrm{~kg} \mathrm{COD} \cdot \mathrm{m}^{-3} \cdot \mathrm{d}^{-1}$ (Fig. 2).

\section{Reactor stabilisation}

During the period Day 14 to 35, the influent COD load was kept constant at $2200 \mathrm{mg} \cdot \ell^{-1}\left( \pm 360 \mathrm{mg} \cdot \ell^{-1}\right)$ and the COD reduction 


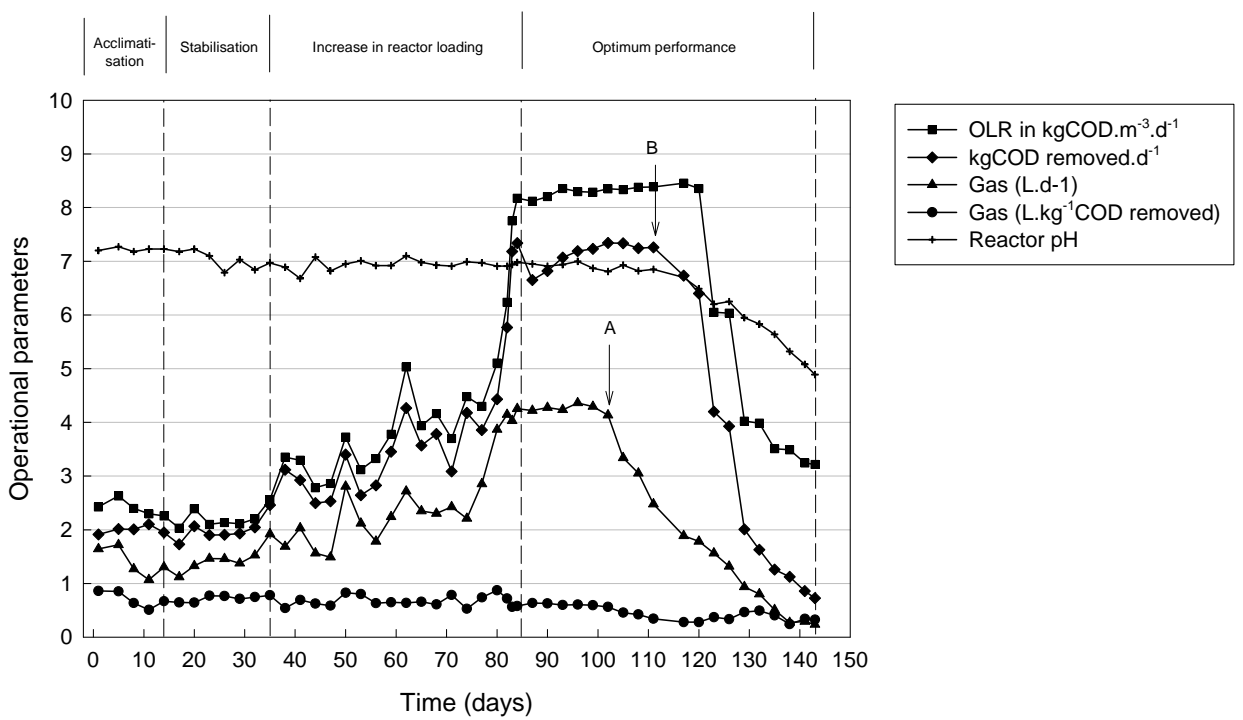

Figure 2

Operational parameters of the UASB reactor treating a high alkaline fruit cannery lyepeeling wastewater $(A-G a s$ production decreased on day 102; $B-C O D$ reduction and $\mathrm{pH}$ decreased after day 111).

was found to vary between 85 and $96 \%$ (Fig. 1). The reactor effluent $\mathrm{pH}$ varied between 6.80 and 7.23 , the average OLR for this period was $2.20 \mathrm{kgCOD} \cdot \mathrm{m}^{-3} \cdot \mathrm{d}^{-1}$ and biogas production remained relatively constant at $1.4 \ell \cdot \mathrm{d}^{-1}$ (Fig. 2).

\section{Increase in reactor loading}

The influent COD was gradually increased, during Days 36 to 85 , to a maximum of $8200 \mathrm{mg} \cdot \ell^{-1}$, with the OLR reaching $8.10 \mathrm{kgCOD} \cdot \mathrm{m}^{-3} \cdot \mathrm{d}^{-1}$ on Day 85 . The COD reduction remained at an average of $90 \%$ (83.5 to $93.2 \%$ ) (Fig. 1) The biogas production was also found to increase from 1.4 to $4.0 \ell \cdot \mathrm{d}^{-1}$ by Day 85 . During this period the reactor effluent $\mathrm{pH}$ varied between 6.70 and 7.10 (Fig. 2).

\section{Optimum performance}

From Day 85 to 120 the influent COD was kept constant at 8300 $\mathrm{mg} \cdot \ell^{-1}$ (8 120 to $\left.8456 \mathrm{mg} \cdot \ell^{-1}\right)$. A COD reduction of between 82 and $90 \%$ was achieved (Fig. 1) and the effluent $\mathrm{pH}$ was found to vary from 6.78 to 6.98 (Fig. 2) until Day 111. After Day 111 it was found that the COD and $\mathrm{pH}$ had decreased to $76 \%$ and 6.49, respectively. Methanogens are known to be inhibited at $\mathrm{pH}$ levels of below 6.5 (Lin and Yang, 1991; Droste, 1997; Bitton, 1999). On Day 121 the influent COD concentration was lowered to $6000 \mathrm{mg} \cdot \ell^{-1}$ in an attempt to stabilise the reactor system $\mathrm{pH}$ and COD reduction by lowering the fermentable carbon source. The COD reduction, however, continued to decrease and two subsequent decreases in influent COD to $4000 \mathrm{mg} \cdot \ell^{-1}$ on Day 129 and to $3500 \mathrm{mg} \cdot \ell^{-1}$ on Day 135, were also unsuccessful in stabilising the COD reduction efficiency or $\mathrm{pH}$, which continued to drop after Day 120 to Day 143 indicating that acidification of the reactor had taken place. The COD reduction decreased from $76 \%$ on Day 120 to below $50 \%$ on Day 129 and to 22\% after $143 \mathrm{~d}$. During this same period the reactor effluent $\mathrm{pH}$ decreased from 6.49 on Day 120 to 5.95 on Day 129 and 4.89 after $143 \mathrm{~d}$.

The gas production after Day 85 remained relatively constant at ca. $4.1 \ell \cdot \mathrm{d}^{-1}$ (63\% methane), until Day 102, whereafter the gas production decreased to $2.48 \ell \cdot \mathrm{d}^{-1}$ (48\% methane) by Day 111 and to $0.93 \ell \cdot d^{-1}(22 \%$ methane) by Day 129 . The data show that the gas production started to decrease (Day 102) before any other negative tendencies were observed in either COD reduction or reactor effluent $\mathrm{pH}$. This dramatic decrease in the methanisation rate could possibly be as a result of the high levels of sodium (influent $\mathrm{Na}^{+}$concentration of $c a .7300 \mathrm{mg} \cdot \ell^{-1}$ ) accumulating in the reactor. It has been reported that sodium, at low concentrations, is essential for methanogens, probably because of its role in the formation of adenosine triphosphate (ATP), the oxidation of NADH (Feijoo et al., 1995) or in the chemi-osmotic coupling mechanism (Rinzema et al., 1988). It has also been shown that the presence of high sodium concentrations (10 000 to 25000 $\left.\mathrm{mg} \cdot \ell^{-1}\right)$ is inhibitory to anaerobic wastewater treatment in that methanogenesis is inhibited to varying degrees (Feijoo et al., 1995).

In this study the sodium concentration of the initial diluted lye-peeling substrate was ca. $2000 \mathrm{mg} \cdot \ell^{-1}\left( \pm 200 \mathrm{mg} \cdot \ell^{-1}\right)$. When the influent COD concentration was at a maximum of $8300 \mathrm{mg} \cdot \ell^{-1}$ (Days 85 to 120), the sodium concentration of the substrate was ca. $7300 \mathrm{mg} \cdot \ell^{-1}$. During this period the sodium concentration of the reactor effluent varied between 6800 and $7200 \mathrm{mg} \cdot \ell^{-1}$. The difference in reactor influent and effluent $\mathrm{Na}^{+}$concentrations would suggest an accumulation of sodium within the reactor's biomass. Based on the rapid decrease in $\mathrm{CH}_{4}$ production, it is possible that accumulation of sodium within the system led to the inhibition of the methanogenic population, with subsequent acidification of the entire system and accumulation of volatile fatty acids.

The above data are in agreement with reports by De Baere et al. (1984) who investigated the effect of $\mathrm{NaCl}$ shock treatments on a flow-through anaerobic digester. They reported that initial inhibition and a 50\% inhibition were observed at 30000 and $35000 \mathrm{mg} \cdot \ell^{-1}$ sodium, respectively. According to these authors adaptation to increasing amounts of $\mathrm{NaCl}$ significantly affected the tolerance of the methanogenic association when compared to the shock treatment. With adaptation, an initial inhibition was observed at $65000 \mathrm{mg} \cdot \ell^{-1}$ and $50 \%$ inhibition at $95000 \mathrm{mg} \cdot \ell^{-1}$ of $\mathrm{NaCl}$. Feijoo et al. (1995) reported that sodium concentrations ranging from 3000 to $16000 \mathrm{mg} \cdot \ell^{-1}$ (in the absence of nutrients or other salts) caused a $50 \%$ inhibition in the methanisation of volatile fatty acids. Rinzema et al. (1988) found that the maximum specific acetoclastic activity of granular sludge was hardly affected at sodium concentrations of below $5000 \mathrm{mg} \cdot \ell^{-1}$ (10\% inhibition), whereas the activity was practically reduced to zero at $14000 \mathrm{mg} \cdot \ell^{-1} \mathrm{Na}^{+}$. In UASB systems, the results were slightly more favourable, with $10 \%$ and $100 \%$ inhibition at 5500 and $15000 \mathrm{mg} \cdot \ell^{-1} \mathrm{Na}^{+}$, respectively (Rinzema et al., 1988). Kim et al. (2000) also found that methane production decreased with increases in sodium concentrations above $5000 \mathrm{mg} \cdot \ell^{-1}$ and 
that at $20000 \mathrm{mg} \cdot \ell^{-1}$ a $50 \%$ reduction in theoretical gas volume was observed. In this study, it was clear from the concentration of sodium in the reactor effluent that the level of accumulated sodium in the reactor could readily have reached levels of $>20000 \mathrm{mg} \cdot \ell^{-1}$.

\section{Conclusions}

In this study, digestion of the organic fraction present in fruitcannery lye-peeling wastewaters was again shown to be a feasible treatment option, with COD reductions of up to $95 \%$ being obtained. Furthermore, it would appear that the microbial consortium involved in the anaerobic digestion process can acclimatise to higher sodium-ion levels present in the wastewater. This is in agreement with observations in the literature. However, accumulation of sodium ions within the reactor biomass to levels of above $15000 \mathrm{mg} \cdot \ell^{-1} \mathrm{can}$ also become detrimental to the overall stability of the reactor, inhibiting the anaerobic digestion process, leading to decreased COD reduction (decreased from $90 \%$ to $22 \%$ ), gas production (decreased from 4.1 to $\left.0.93 \ell \cdot \mathrm{d}^{-1}\right)$ and reactor acidification ( $\mathrm{pH}$ dropped from 6.98 to 4.89). It appears that the methanogens are more sensitive to higher sodium levels, as the biogas and methane percentages were the first parameters to change. Decreases in methane production could thus be an early warning system of sodium accumulation or toxicity and should thus be closely monitored in systems treating wastewaters containing high sodium concentrations. In the case of fruit-cannery wastewaters, it would also be advisable to integrate the highly alkaline lye-peeling wastewater with other wastewaters generated in the canning process, in order to dilute the sodium-ion concentration, so as to lower the risks of negatively affecting the efficiency of anaerobic digestion processes. From the data obtained in this study it was also considered important to examine the use of additional chemical processes to facilitate the decrease of the organic load of the fruit-cannery wastewater following the UASB treatment, in order to meet the $75 \mathrm{mg} \cdot \ell^{-1}$ 'general' legal limit for discharge to a natural water system.

\section{References}

AUSTERMANN-HAUN U, MEYER H, SEYFRIED CF and ROSENWINKEL K-H (1999) Full scale experiences with anaerobic/aerobic treatment plants in the food and beverage industry. Water Sci. Technol. 40 (1) 305-312.

BITTON G (1999) Wastewater Microbiology. John Wiley and Sons, Inc., New York, USA. 169-365, 387-426.

DE BAERE LA, DEVOCHT M, VAN ASSCHE P and VERSTRAETE $\mathrm{W}$ (1984) Influence of high $\mathrm{NaCl}$ and $\mathrm{NH}_{4} \mathrm{Cl}$ salt levels on methanogenic associations. Water Res. 18 (5) 543-548.

DROSTE RL (1997) Theory and Practice of Water and Wastewater Treatment.: John Wiley and Sons, Inc., New York, USA. 670-708.

FEIJOO G, SOTO M, MÉNDEZ R and LEMA JM (1995) Sodium inhibition in the anaerobic digestion process: Antagonism and adaptation phenomena. Enzyme Microb. Technol. 17 180-188.
FRANKIN RJ (2001) Full-scale experiences with anaerobic treatment of industrial wastewater. Water Sci. Technol. 44 (8) 1-6.

GAMBRELL RP and PEELE TC (1973) Disposal of peach cannery waste by application to soil. J. Environ. Qual. 2 (1) 100-104.

GRAY MG (1999) Recent environmental law developments in South Africa: The Constitution, the National Environmental Management Act and the National Water Act: Impacts, Impressions and Industry. Proc. Afr. Int. Environ. Protect. Symp. incorporating the $4^{\text {th }}$ South. Afr. Anaerobic Digestion Symp. 1999. Pietermaritzburg, South Africa.

HANKS FJ, LAMBERT JR and OPLIGER PS (1968) Hydrologic and quality effects of disposal of peach cannery waste. Trans. ASAE $\mathbf{1 1}$ (1) 90-93.

HARADA H, MOMONOI K, YAMAZAKI S and TAKIZAWA S (1994) Application of anaerobic-UF membrane reactor for treatment of a wastewater containing high strength particulate organics. Water Sci. Technol. 30 (12) 307-319.

IKHU-OMOREGBE DIO and MASIIWA H (2002) A postal survey of effluent generation and disposal in the Zimbabwean dairy industry. Water SA 28 (2) 179-182.

KIM IS, KIM DH and HYUN S-H (2000) Effect of particle size and sodium ion concentration on anaerobic thermophilic food waste digestion. Water Sci. Technol. 41 (3) 67-73.

LIN K-C and YANG Z (1991) Technical review on the UASB process. Int. J. Environ. Stud. 39 203-222.

MAWSON AJ (1997) Regeneration of cleaning and processing solutions using membrane technologies. Trends Food Sci. Technol. 8 7-13.

McLACHLAN T (2004) Integration of a Combined UASB-Ozonation Treatment System for Cellar Effluent Degradation. M.Sc. in Food Science Thesis, University of Stellenbosch, South Africa.

MEYER LH, HUGO AB, BRITZ TJ, DE WITT B and LATEGAN PM (1985) Temperature control for laboratory-scale anaerobic digesters. Water SA 9 (2) 79-80.

MONSON H (1959) Cannery waste disposal by spray irrigation - after 10 years. Proc. $13^{\text {th }}$ Industrial Waste Conference. Date?Purdue University, USA. 449-455.

NEL LH, BRITZ TJ and LATEGAN PM (1985) The effect of trace elements on the performance efficiency of an anaerobic fixed film reactor treating a petrochemical effluent. Water SA 11 (3) 107-110.

REPUBLIC OF SOUTH AFRICA (1998a) National Environmental Management Act - Act No 107:1998. Section 31: The Open Democracy Bill. Office of the President, Pretoria, South Africa.

REPUBLIC OF SOUTH AFRICA. (1998b). Water Act - Act No 36:1998. Government Notice No: 19182. Vol. 398. Office of the President, Pretoria, South Africa.

RINZEMA A, VAN LIER J and LETTINGA G. (1988). Sodium inhibition of acetoclastic methanogens in granular sludge from a UASB reactor. Enzyme Microb. Technol. 10 24-32.

STALZER WF (1976) Cannery wastes and their treatment by the activated sludge process. Progr. Water Technol. 8 (2/3) 359-368.

STANDARD METHODS (1998) Standard Methods for the Examination of Water and Wastewater (20 $0^{\text {th }}$ edn.). American Public Health Association (APHA), Washington, DC.

TRNOVEC W and BRITZ TJ (1998) Influence of organic loading rate and hydraulic retention time on the efficiency of a UASB reactor treating a canning factory effluent. Water SA 24 (2)147-152.

WAYMAN MJV (1996) Water supplies, effluent disposal and other environmental considerations. In: Arthey D and Ashurst PR (eds.) Fruit Processing. Blackie Academic and Professional, London, UK. 221-243. 